\title{
Gender- and SES-Specific Disparities in Shadow Education: Compensation for Boys, Status Upgrade for Girls? Evidence From the German LifE Study
}

\author{
Steve R. Entrich \\ University of Potsdam, Inclusion and Organizational Development \\ Wolfgang Lauterbach \\ University of Potsdam, Social Science Education Research
}

\begin{abstract}
In the present article, we draw on social reproduction theories to explain the increase in the use of "shadow education" (SE) in Germany over the last two decades as a status-based, gender-specific investment strategy of families. Thus, we ask whether investing in private tutoring for both girls and boys alike serves to maintain or improve their status position, or whether gender-specific investment strategies exist. Our hypotheses are quantitatively tested by means of logistic regression using data of the 2012 German Life Courses into Early Adulthood (LifE) study. In contrast to prominent beliefs, our results show that SE in Germany does not function as a tool to promote social inequality. Instead, SE is used largely independent of social origin to achieve higher educational credentials. We found that particularly boys from non-academic but high-income families use SE, whereas girls seem unaffected by social origin entirely. Our findings call for further strengthening the gender dimension in existing inequality theories.
\end{abstract}

Keywords: social inequality, gender inequality, private tutoring, shadow education, German LifE study

In Germany, the proportion of 17-year olds who received shadow education (SE) (Bray, 1999, 2009, 2017; Byun, Chung, \& Baker, 2018; Entrich, 2018; Stevenson \& Baker, 1992), ${ }^{1}$ has rapidly increased from 27 percent in the early 2000 years to 47 percent in the early 2010 years (Hille, Spieß, \& Staneva, 2016, p. 116). ${ }^{2}$ Although participation during primary school remains low (reaching $8 \%$ in fourth grade), it increases rapidly following the transition to secondary school, with every fifth student receiving $\mathrm{SE}$ in grades nine and ten (ibid.). It is estimated that each year about 1.1 million students subscribe to programs in the private tutoring market (Klemm \& Klemm, 2010), which is dominated by 4,500 tutoring schools, mostly founded since 1992 (Birkelbach, Dobischat, \& Dobischat, 2017, pp. 59-62). Annual profits of up to 1.5 billion Euros are the result (Klemm \& Klemm, 2010). Thus, SE is a widespread family strategy to promote educational attainment of children. In the present

1 In Germany, any kind of tutoring is called "Nachhilfe" (extra-help). We focus our analysis on private, fee-based, commercial tutoring, which fits the formal definition of shadow education (SE) by Bray (2017). The terms shadow education and private tutoring are used synonymous.

2 Based on national representative samples for 2000 to 2003 and 2009 to 2013, respectively. 
14 article, the observed increase in the use of SE in Germany is theoretically derived and empirically examined as a consequence of status-based, gender-specific investment strategies of families.

Previous German and international studies on SE generally agree that (a) students from families with higher socioeconomic status (SES) use SE more frequently than lower SES students, thus indicating that SE exacerbates social disparities in educational attainment (e.g., Bray, 2009; Byun et al., 2018; Dohmen, Erbes, Fuchs, \& Günzel, 2008; Entrich, 2020; Guill \& Lintorf, 2019; Hille et al., 2016; Park, Buchmann, Choi, \& Merry, 2016). Only few studies provide (b) empirical evidence suggesting that SE may be used independent of SES, simply to compensate low school performance (see Abele \& Liebau, 1998; Entrich, 2018; Guill \& Bonsen, 2011; Luplow \& Schneider, 2014; Seiyama \& Noguchi, 1984). International research also reported (c) a higher likelihood of girls to use SE in several countries, (e.g., USA: Buchmann, Condron, \& Roscigno, 2010; Japan: Entrich, 2015; Korea: Lee \& Shouse, 2011), but not in others (e.g., Germany: Hille et al., 2016; China: Liu \& Bray, 2016; Poland: Safarzynska, 2013). However, for Germany we find (d) gender specific investment by school subject (Dohmen et al., 2008, p. 40). Furthermore, recent research (e) stressed that families generally make gender-specific educational investments, which are confounded by their SES (e.g. Becker \& Müller, 2011; Breen, Luijkx, Müller, \& Pollak, 2012; Hadjar \& Berger, 2010; Lühe, Becker, Neumann, \& Maaz, 2016, 2017). Whether family SES explains differences in the gender specific use of SE has never been in the focus of any study. Gender - if considered at all - has always been treated as a control variable or complimentary factor in past research.

Based on these findings, we invest in three questions: Is SE more likely in high SES families, or is it used across all social strata to compensate for underperformance in school? Second, are there gender differences in the use of SE, differentiated by SES? Third, how do both findings affect social reproduction mechanisms? The last question is significant, as the frequent use of SE can lead to dislocations in the educational process of children and youth, as shown in studies concerned with shadow education in East Asia (e.g. Byun, 2014; Entrich, 2018; Stevenson \& Baker, 1992), for example.

In order to answer these questions, we follow previous research findings and draw on social reproduction theories (Boudon, 1974; Breen \& Goldthorpe, 1997; Lucas, 2001). We ask whether investing in SE for girls and boys serves to maintain or even increase their status position, or whether there exist status-specific gender preferences for SE investment. The derived hypotheses are quantitatively tested by means of logistic regressions using data of the 2012 German Life Courses into Early Adulthood (LifE) study (Lauterbach, Fend, \& Gläßer, 2016). 


\section{Past research on shadow education and inequality}

\subsection{Shadow education as SES-specific investment?}

International research confirmed that underperformance in academic school subjects (language, math, English, and MINT-subjects) is the main motive for SE attendance in most countries (Baker, Akiba, LeTendre, \& Wiseman, 2001; Bray, 2009; Byun et al., 2018; Entrich, 2018; Park et al., 2016), including Germany (Birkelbach et al., 2017; Guill \& Lintorf, 2019; Jürgens \& Diekmann, 2007; Luplow \& Schneider, 2014; Schneider, 2005). The same research argues that high SES (measured in terms of parental education, occupation and income) families are generally more likely to invest in SE than low SES families.

But for Germany the influence of socio-economic factors was only partially proven. Some studies report considerable effects of household income on SE participation (Hille et al., 2016; Schneider, 2005), while others report no such effects (Abele \& Liebau, 1998; Guill \& Lintorf, 2019; Luplow \& Schneider, 2014). Similarly, some studies found that academic parents tend to not send their children to SE in Germany (Entrich \& Lauterbach, 2019; Hille et al., 2016; Luplow \& Schneider, 2014; Schneider, 2005), while others reported a significantly higher likelihood of children with academic parents to obtain SE (Guill \& Lintorf, 2019; Guill, Lüdtke, \& Köller, 2020). We suspect that the differences in the effect of the SES of the students are related to the measurement of the variables and the construction of the models. It is striking, for example, that the influence of educational variables on the use of SE only shows positive significant effects in studies that do not differentiate between paid and unpaid tutoring. Moreover, the measurement and number of SES variables included in the anlysis vary from study to study.

In addition to SES, exaggerated educational aspirations of upper strata parents are constantly discussed as a cause for the increased use of SE in Germany. It is assumed that academically educated parents from high-income households in particular demand tutoring to provide their children with a competitive advantage in the form of above-average grades (Hollenbach \& Meier, 2004; Klemm \& Hollenbach-Biele, 2016; Koinzer, 2013; Schlösser \& Schuhen, 2011). This way, high SES families try to make sure that their children achieve above average school leaving degrees, enter tertiary education and get access to high-rewarding jobs. Several studies from international research on SE support this prominent claim (see Bray, 1999, 2009). Accordingly, the more cost-intensive lessons specializing on entrance exam preparation as the most prominent way to achieve competitive advantages for high performing students (enhancement features) are more frequently pursued by high SES students (e.g. USA: Buchmann et al., 2010; South Korea: Byun, 2014; Japan: Entrich, 2018; England: Ireson \& Rushforth, 2011). However, reliable studies on the effectiveness of SE in Germany indicate that low-performing students may not catch up to their peers through additional tutoring (Entrich, 2014a; Guill et al., 2019; Ömeroğulları, Guill, \& Köller, 2020). Empirical evidence refuting the assumption 
16 that well-performing high SES students use SE to gain competitive advantages for educational placement is still pending, though.

\subsection{Shadow education as gender-specific investment?}

Figure 1 shows gender specific participation in SE in Germany from 2000 to 2015 against the background of educational expansion. Findings show that girls more often achieve the highest formal school degree available in Germany, the Abitur (2015: $58.6 \%$ girls; $49.4 \%$ boys), and enter universities more frequently nowadays (2015: $60.5 \%$ girls; $56.1 \%$ boys). ${ }^{3}$ Alongside this development, there has been a clear upward trend in the demand for SE between 2000 and 2010. Since 2010, the SE experience of 17-year-olds stabilized well beyond 40 percent for both male and female students (2015: about $42 \%$ for boys and $43 \%$ for girls).



Figure 1 Percentage of Abitur graduates, entrants to universities and participation in paid tutoring in Germany, according to gender (in \%, 2000-2015)

Notes: Abitur graduation rates as a proportion of the respective age population of the corresponding year; university enrolment rates as a proportion of first-year students of the population of the corresponding year of birth; Nachhilfe experience rate based on the item: Did you ever obtain paid Nachhilfe? (Yes/No), showing the weighted mean of 17-year-old participants according to birth cohorts (2000: born 1982-84; 2005: born 1987-89; 2010: 1992-94; 2015: 1997-99), SOEP adolescent survey. Sources: Own calculations based on Helbig (2012); Statistisches Bundesamt; SOEPv36.

3 It has to be noted that not all individuals who achieve the Abitur enter university afterwards, many also enter vocational programs instead. The high entrance rates are thus also an outcome of greater openness in access to university, since individuals without the Abitur are increasingly allowed to enter a range of study programs at university if they have completed a related dual vocational training program of generally three years instead of the Abitur, for example. 
In line with research on differences in subject-specific performance by gender

(e.g. DiPrete \& Buchmann, 2013; Hadjar, 2011; Helbig, 2012), gender differences in the use of tutoring according to school subjects are often reported. Existing primarily descriptive findings indicate that boys show on average lower achievement in languages (German and English) and are more likely to use tutoring in related subjects, whereas girls show on average lower performance and thus higher demand for tutoring in mathematics (Dohmen et al., 2008; Guill \& Bonsen, 2011; Hollenbach \& Meier, 2004; Jürgens \& Diekmann, 2007; Rudolph, 2002). Yet, studies explicitly examining the gender-specific use of private tutoring are not available.

\subsection{Intersectionalities between gender and SES in shadow education investment?}

Subject domain-specific differences in academic achievement by gender are often confounded with parental SES. Using data from the Berlin study for fourth grade students, Lühe et al. (2016) point to systematic SES-specific differences in performance between boys and girls in elementary school. Boys show greater variation in academic performance measured by grades across social strata than girls. In all three investigated domains, i.e. reading, German and mathematics, boys from high SES families showed higher performance compared to girls from similar strata. The opposite was found for low SES boys. The authors attribute this mainly to strong traditional concepts of masculinity, which are more prevalent in low SES households. In a different analysis based on national representative data from the 2006/07 TIMSS survey, the authors showed that there are only marginal performance differences between boys and girls, differentiated by social origin. Striking, however, is the high gender-independent performance among high SES groups (Lühe et al., 2017).

Past research has also shown that parents' educational aspirations for children's secondary school choice have largely converged for girls and boys with similar performance (Helbig, 2012). In addition to the "de-traditionalization" of gender roles, evidence suggests that educational aspirations of girls and parental aspirations for daughters have increased, partly favoring investment in the education of daughters over sons (Helbig, 2013). Whether parents favor girls or boys in their private tutoring investment is not clear and was hardly investigated. One exception is the study by Seiyama and Noguchi (1984), which demonstrated gender- and SES-specific differences in the likelihood to obtain tutoring in Japan. Findings show that high SES families invest more in the SE of boys than girls, especially if boys are high performers. Girls received SE independent of their grades and family background, and gained significant performance improvement - boys did not.

The SES-specific differences in the appreciation and attribution of traditional gender roles, including resulting gender-specific educational aspirations, which partly explain the higher performance and success rates of girls in high schools and universities, suggest SES-specific investment in private tutoring by gender in Germany as well. 
In sociological educational research, rational choice theories (Boudon, 1974; Breen $\&$ Goldthorpe, 1997) are often used to understand social inequality in educational attainment (e.g. Baumert, Maaz, \& Trautwein, 2010; Becker \& Lauterbach, 2016). Two effects of social stratification have been identified as causing social reproduction: First, SES-specific differences in learning habits and family support often lead to differences in academic achievement. Students from low SES families often show lower performance than privileged students (primary effect). Second, based on SES-specific educational aspirations, parents seek to ensure that their children achieve at least a position in the same class as themselves (secondary effect). All families are anxious to avoid downward social mobility, particularly through investment in education (status maintenance motive). However, the actual risk taking based on the risk aversion level varies across social strata. High SES parents are more likely to choose educational programs promising high returns despite having high risk aversion; under the same circumstances, low SES parents tend to choose programs with lower returns. Hence, different decisions are made by different strata, even if the performance of the students is the same (Breen \& Goldthorpe, 1997).

According to effectively maintained inequality (EMI) theory, the central status maintenance motive involves exhausting all possible resources to avoid a decline in status. Two major dimensions of education affect status stability: a quantitative (e.g., obtained number of years of education) and a qualitative dimension (e.g., pursued study program/track) (Lucas, 2001). If the majority of students attend upper secondary school, for example, high SES families will try to place their children in more advantageous degree programs. However, if, as happened in Germany, more than every second student achieves the most advantageous school leaving degree, the Abitur, the value of this certificate is no longer measured solely by its "possession", but in relation to the number of students who also earn this degree (Shavit \& Park, 2016). The more students achieve the Abitur, the more students will compete for coveted positions in the labor market and for seats at university, which increases the cohort competition. Especially high SES parents will then seek new opportunities for their children to secure competitive advantages for status maintenance, shifting their focus to increasing the relative value of the degree, i.e. its grade point average.

From this perspective, the investment in $\mathrm{SE}$ is a rational decision of forward-looking parents to support the school performance of their children, considering the related costs and benefits (Entrich, 2018; Guill, 2012; Luplow \& Schneider, 2014; Schneider, 2005). The use of SE can serve two functions related to status maintenance and upgrade motives: (1) compensation of below average performance to prevent dropping out from the competition for educational qualifications; and (2) enhancement of average/good performance to attain a competitive advantage within the same school degree program, i.e. improvement of grades above the average (Entrich \& Lauterbach, 2019). 
If high SES families make more use of one or both functions of SE than low SES families and given that these investments show positive effects, social inequality would be strengthened. However, if we take into account the findings from research on the effects of SE in Germany, it appears doubtful that children gain any significant long-term performance improvement from their use of tutoring. Instead, reliable research based on national representative (panel) data shows that students achieve nearly no improvement in performance through tutoring - tutees remain at their respective performance levels. Students continue to show low performance even if they receive tutoring (Dohmen et al., 2008; Entrich, 2014a; Guill \& Bos, 2014; Guill et al., 2019; Guill \& Spinath, 2014; Hosenfeld, 2011; Ömeroğulları et al., 2020). This indicates a primarily compensatory function of SE: SE helps students to keep their (often low) performance level, achieve a certain degree and avoid dropping out of school. Since high SES parents can provide better support for their children, children from these families show on average better performance and have also less need for compensatory tutoring, though. In order to function as a status maintenance tool for high strata, students from high SES families would need to use SE significantly more frequently to maintain their (often high) performance. Only then, social inequality would be positively affected.

However, we doubt that parents' socioeconomic background and their aspirations show similar strong effects on SE attendance in Germany as found in other national settings (e.g. East Asia; Entrich, 2018). Due to the educational expansion in Germany, more students from disadvantaged SES backgrounds achieve a university entrance qualification (Abitur) instead of the less prestigious lower secondary and intermediate degrees at the Haupt- and Realschule, respectively. ${ }^{4}$ But, since low and middle SES parents seldom possess the Abitur themselves, they often lack the competence to support their children in achieving this degree. Thus, the increased demand for SE may be caused especially by students from non-academic families and their higher need for compensatory tutoring due to higher requirements at higher levels/tracks of schooling. If low SES strata make substantial use of SE, this may compensate the SES gap in average school performance and cognitive ability enough to cope with the higher requirements of more demanding tracks. This would enable these students to achieve higher degrees than their parents, thereby weaken social reproduction in educational attainment. This argumentation leads to the first set of hypotheses: Contrasting to arguments from social reproduction theories, we expect that lower SES families are generally more likely to use SE in Germany. More specific,

The German secondary school system provides students with the opportunity to choose between three general tracks of different length, curriculum and expectable returns: (1) The upper secondary school degree (Abitur, 12 to 13 years), traditionally obtained at the Gymnasium, provides students with the opportunity to enter university and thus gain access to the most prestigious and rewarding jobs. (2) The intermediate degree (10 years; Realschule) provides access to those parts of the dual vocational training system leading to white collar jobs. (3) The least demanding lower secondary degree ( 9 years; Hauptschule) enables graduates to enter those parts of the dual vocational training system that lead to blue collar or unskilled jobs (Weiss \& Schindler, 2017). 
20 to achieve status upgrading by attaining the highest school leaving certificate, the Abitur, non-academic parents are more likely than academics to invest in the SE of their children (hypothesis 1-1). We further expect a strong association between the students' performance level and their experience with SE. Specifically, we expect that families are more likely to invest in SE when their children are in danger of early dropout from school due to poor performance (compensation strategy). The empirically proven rather marginal effects of SE on academic achievement indicate that low performing students may keep their grades at a similar level without significantly improving them. Hence, students with below average performance should show the highest likelihood of having obtained SE (hypothesis 1-2). Moreover, we expect that students who continue their school career to upper secondary education and/or enter qualitatively more demanding secondary school tracks, i.e. the Abitur program, are generally more likely to obtain SE (hypothesis 1-3). Since students "might choose divergent educational pathways [and gain] more influence over the decision for shadow education as they grow older" (Entrich, 2015, pp. 212-213), we also expect that - aside the parents' educational aspirations - students' own aspirations positively influence their likelihood to obtain SE (hypothesis 1-4).

In a second step, we extend the above arguments to gender disparities. Following Boudon (1974), gender disparities in educational attainment can be explained analogously to class-specific disparities. For example, stereotypically gendered upbringing and socialization experiences influence students' interests, behaviors, and motivations and affect their subject-specific performance and educational progress (primary effect) (Hadjar \& Berger, 2011; Lühe et al., 2016, 2017). Traditionally, parents favored an investment in the education of boys over girls because, in line with traditional role models and the male breadwinner model, they viewed the education of boys as more important for later income and status. Educational decisions have therefore always been influenced by the gender of the child, with lower educational aspirations for girls compared to boys (secondary effect). Cost-benefit calculations of parents have traditionally turned out to be to the disadvantage of girls, because parents favored their sons to achieve a high education and subsequent status to follow into their (father's) footsteps (ibid.). The status maintenance motive in social reproduction theories thus stronger referred to sons than daughters. However, the recent de-traditionalization of gender roles concomitant with a preference of investing in girls (Helbig, 2012) indicate that families may also favor investing in the SE of their daughters for status maintenance or upgrading.

Because traditional gender role expectations are still more prevalent in low SES families, especially low educated, non-academic families, and least prevalent in high SES families with advantaged educational backgrounds, we suspect that parental status upgrade and maintenance motives are still more traditional in non-academic families. Thus, these families should favor investments in the education of boys over girls for status maintenance and upgrade. Hence, we expect interaction effects between students' gender and parental educational background. Specifically, we expect that boys from non-academic backgrounds are more likely to obtain 
SE than girls from the same background (hypothesis 2-1). Furthermore, we expect larger effects of other SES factors and aspirations on the likelihood that boys from non-academic strata obtain SE. Especially the financial situation of the household should affect whether non-academic families, i.e. low and middle SES strata, can afford tutoring ${ }^{5}$ (hypothesis 2-2). We expect that because non-academic families favor the support of boys over girls in academic matters, girls from non-academic families are less likely to receive tutoring if they show below average grades than girls from academic families. In academic families, children are more equally treated in academic matters, wherefore we expect no concrete differences in the reception of tutoring by performance level between education strata for boys (hypothesis 2-3).

\section{Data and methods}

\subsection{Data: The German LifE study (1979-2012)}

The German "Pathways from Late Childhood to Adulthood" (LifE) study started as a longitudinal youth study in Hesse, one of the federal states of Germany. Annual samples of approximately 2000 children and adolescents of the birth cohort 1967 were collected from 1979 to 1983. 12-year-old students were questioned up to five times during this time period, their parents were questioned two times. The youth study initially focused on urban and rural environments, as well as different school contexts. The study covered students from the former tripartite and comprehensive system ('quasi experimental system'). Thus, an urban region (Frankfurt am Main) of former "West" Germany and adjacent rural areas (Odenwald, Bergstrasse) with different school systems were chosen. The study also focused on juveniles coping with developmental tasks during adolescence, and on the development of personality. As far as representativeness is concerned, it can be said that the families with children aged 12 to 16 years in the years 1979 to 1983 in West Germany are well represented in the sample, because children in this age group were focused at that time (Tsching, Berichte, \& Fend, 1983). The LifE study continued to accompany the former students and collected data again in the years 2002 (age 35) and 2012 (age 45) (Lauterbach et al., 2016).

SE related items were introduced for the first time in 2012. The representative original student sample in 1979-1983 and the now 45-year olds $(\mathrm{N}=1,359$ participants) was supplemented by an additional independent sample of their children, ${ }^{6}$ hence providing us with valuable information on a third generation $(\mathrm{N}=581)$. So in

5 Even though the German government issued a country-wide voucher program ("Bildungsgutschein") in 2011, allowing all low SES households receiving social welfare services ("Hartz 4 ") to apply for fee-based tutoring, if the child shows low performance in school (grades 4 or worse), the use of these services will not be reflected in our data.

6 Only the first-born child in each family aged 12 to less than 18 years was considered. 
22 contrast to studies where only one cohort was sampled and either the parents or the students had to make assumptions on key variables of the other cohort (such as social background estimated by students or school performance estimated by parents; e.g., Entrich, 2014b; Guill \& Lintorf, 2019), we are in a position to use reliable statements of both cohorts and bring them together for our analysis of $\mathrm{SE}$ determinants. More important, we are able to differentiate paid from unpaid tutoring in our analyses, which remains a major shortcoming in many major studies on SE in Germany (e.g., Behr, 1990; Guill, 2012; Guill \& Lintorf, 2019; Guill et al., 2019; Ömeroğulları et al., 2020). The specific design of the complete survey, of the youth study (1979-1983) and the renewed questionnaire surveys in 2002 and 2012 (approximately 30 years later), has a positive selection of the cohort according to following aspects: migration background, school degree and divorces (Lauterbach et al., 2016, pp. 32, 36, 40). Concerning childlessness, there were fewer childless women and men than the average population at the age of 45 years in 2012 and significantly more families with two children (Lauterbach et al., 2016, p. 38). So far, we have not weighted our findings because we were interested in correlations and predictions and not in extrapolating our results to the corresponding population sizes. Due to the uniqueness of the study on the use of private tutoring, this study is very well suited to test the usage behaviour of children according to performance and social background.

\subsection{Variables}

For the 2012 LifE survey, we asked parents the following three questions concerning SE: "Has your child ever received private tutoring during his/her school life? If yes, how often?"; "Did you pay for this tutoring or was it mainly free of charge?"; and "What prompted you to organize private tutoring for your child?" According to our data, in $201244.1 \%$ of the 12 - to 17 -year-old children reported to have received paid tutoring at some point, whereas another $8.2 \%$ obtained free of charge tutoring. Half of all SE recipients (51.4\%) used these lessons to improve their grades in school, $38.4 \%$ pursued SE to prepare for upcoming tests, exams or classes, and $28.1 \%$ demanded individual support, wanted to close gaps of knowledge, or practiced new learning strategies. To investigate whether SE may contribute to educational and social inequalities, we focus our analysis on paid tutoring and encode unpaid and no tutoring as a reference category.

To test our hypotheses, on the parents' side the SES and their educational motivation are used as decisive determinants for an investment in tutoring. In order to take into account all the relevant resources of the family, apart from the highest parental education $(1=$ academic, i.e. one or both parents possess a university degree; and $0=$ non-academic, i.e. parents do not possess university degrees), especially economic (household net equivalent income: 1 = more than $150 \%$ of the average; 2 = average; and $3=$ less than $70 \%$ of the average) and social dimensions of origin (class according to the European Socioeconomic Classification, i.e. ESeC: 
1 = salariat; 2 = intermediate; and $3=$ working class). ${ }^{7}$ In addition, parents' post-secondary educational aspirations for their children $(1=$ university and $0=$ vocational training/no university degree) are included in the analysis.

On the part of the student, gender is of primary interest, which is included as a binary variable ( $1=$ female, $0=$ male) in our analyses. In order to answer our hypotheses, students' academic achievement level in school is important. Thus, we classified students into three different types of performers based on their grades of the last school report in the subjects mathematics, German and English collected at the time of the 2012 survey: above-average (grades 1, 2); average (grade $3=$ reference); and below-average performers (grades $4,5,6$ ). To reflect the requirements at school, the attended school level ( 1 = upper secondary education, grades 10 to 12 ; $0=$ lower secondary education, grades 5 to 9$)$ and the school track ( 1 = Abitur track; $0=$ Real - or Hauptschule degree programs) are included. Furthermore, we control for the students' own post-secondary educational aspirations ( 1 = university degree, $0=$ vocational training $/$ no university degree) ${ }^{8}$

\subsection{Temporal structure between dependent and independent variables}

Although the data do not accurately capture the time structure between the use of tutoring and the measurement of performance, we can state that there is no bias in the calculation of effect sizes. The majority of the students were interviewed in grades 7 to 10 and research shows that students take SE mostly in these grades (Hille et al., 2016). In addition, research shows clearly that pupils achieve little, if any, improvement in performance through tutoring and generally remain at their respective performance levels, i.e. show high, average or low performance (Dohmen et al., 2008; Entrich, 2014a; Guill \& Bos, 2014; Guill et al., 2019; Guill \& Spinath, 2014; Hosenfeld, 2011; Ömeroğulları et al., 2020). This indicates that SE primarily takes on a compensatory function, i.e. helping students in each performance group to maintain their level of performance, but not to increase it significantly. In order to be used as a status maintenance tool for high strata, students from high SES families would have to have used SE in the course of their school career to maintain their

7 The ESeC is used to classify European societies into nine categories, ranging from higher professions and management occupations to unskilled workers. We recoded these nine groups into three broad classes: the salariat (categories 1 and 2), the intermediate (categories 3, 4, 5, and 6), and the working class (categories 7, 8, and 9) (for a detailed overview see Wirth \& Fischer, 2008).

8 The LifE study also includes data on the parents' and students' idealistic and realistic educational aspirations for the highest school leaving degree. Based on our theoretical arguments we found it more promising to focus on post-secondary aspirations instead, because we believe that these measures better relate to status upgrade and maintenance motives of families. Supplementary analyses not shown here support this notion. We tested the effects of post-secondary and school-leaving degree aspirations both separately and together in all our models and found robust effects of post-secondary aspirations, but no effects for school-leaving degree aspirations. 
24 high performance. When exactly this was the case and for how long is of secondary importance, because we are not interested in testing whether the students' academic achievement has led to the use of tutoring at a certain point in time. Rather, we investigate whether students with different levels of performance (high, medium, low) are more likely to have obtained tutoring and how this is related to their gender and social origin, which allows drawing conclusions about specific investment strategies of families.

\subsection{Methods and analysis strategy}

We first look at descriptive data, before conducting multivariate binary-logistic regression analyses to predict students' likelihood to receive paid SE in secondary school by social origin and gender. ${ }^{9}$ To statistically limit the conditions under which families choose to invest in SE for their children, first, we present a model including all relevant variables step by step. Second, we differentiate the complete model by gender, and third, by the educational background of parents. Instead of reporting logistic coefficients or odds ratios, we show average marginal effects (AME). AME show how many percentage points the average probability of the represented group of one variable is different from the probability in the reference group, while ensuring comparability between models and groups (Mood, 2010). Finally, to test whether the interactions between gender and educational background are significant, we performed logistic regressions interacting all predictor variables with the respective subsample variables (gender and/or educational background).

\subsection{Missing data}

Overall, the proportion of missing values for our sample was very low. Yet, besides gender, there are variables with some missing values, varying between 1.9\% (income) and $7.2 \%$ (school track). Our sample has 549 cases ( 285 girls and 264 boys), for which the following missing values remained: $2.7 \%(N=15)$ for parental class; $0.6 \%(N=3)$ for educational aspirations of parents; $1.8 \%(N=10)$ for grades in math and German, respectively; $2.7 \%(N=15)$ for grades in English; 3.6\% $(N=20)$ for students' school level; $7.5 \%(N=41)$ for school track; and $2 \%(N=11)$ for educational aspirations of students (see also Table 1). To avoid further reduction of our sample and biased parameter estimates due to missing values, we carried out multiple imputation (Schafer \& Graham, 2002). We used the multiple imputation chained equations (MICE) routine implemented in STATA 14 for imputing the missing values (Marchenko, 2011). In total, we imputed 10 data sets including all covariates, the outcome variable, and additional auxiliary variables in the predictor models.

$9 \quad$ All statistical analyses were performed using STATA 14. 


\section{Results}

\subsection{Descriptive statistics}

Table 1 shows descriptive findings. ${ }^{10}$ According to our data and in line with national representative findings, there are no significant gender differences in the use of SE (girls $42.1 \%$ / boys $46.2 \%$, $t$-test: .291). In contrast to prominent assumptions, we find hardly any differences in the use of SE according to class, household income or educational aspirations of the parents. Parental education level is even negatively associated with tutoring: only $34.8 \%$ of the children from academic families, but almost every second child from non-academic families (49.5\%) obtained paid tutoring, which is statistically significant. Reinforcing social inequality through SE is unlikely on the basis of these findings. Rather, students from different SES families seem to receive SE similarly often.

In contrast, very much as expected, students' school achievements in mathematics, German and English are obviously related to SE. Twice as much low performing students (about 60\%) obtained SE compared to high performing students (about $30 \%$ ). The percentage of average performers using SE is considerable, though (about $50 \%$ ). The highest SE demand show those already attending the upper secondary school level (50.7\%) and aspiring to achieve the Abitur (46.3\%). This supports our assumption that paid tutoring is often used by students to compensate for the higher requirements towards the end of their studies and generally when entering qualitatively more demanding school tracks. Students' own educational aspirations show hardly any differences.

Differentiating the use of SE by gender partially questions these findings. We found significant differences in the use of tutoring by parental education and aspirations for boys, of whom a much higher proportion from non-academic backgrounds (about 54\%) and with parents without tertiary education aspirations (about $50 \%$ ) obtained SE compared to those from academic families (about 29\%) and without parents with tertiary education aspirations (about 37\%). This already indicates a higher overall need to compensate low performance of boys from non-academic educational backgrounds. In contrast, there are no significant gender differences in SE use evident for children from high SES families, i.e. where parents possess a university degree, belong to the high-income group and to the salariat, and have high aspirations.

10 Additionally, we tested for statistical significance in the difference between variables using $t$-tests. 
26 Table 1 Use of SE according to SES, educational aspirations, school performance, and degree program/school level

\begin{tabular}{|c|c|c|c|c|c|}
\hline & \multirow{2}{*}{$\begin{array}{c}N \\
\text { (total) }\end{array}$} & \multicolumn{3}{|c|}{ Proportion of SE users (in \%) } \\
\hline & & & Total & $\begin{array}{c}\text { Boys } \\
(N=264)\end{array}$ & $\begin{array}{c}\text { Girls } \\
(N=285)\end{array}$ \\
\hline \multicolumn{2}{|c|}{ Use of paid Nachhilfe... } & 549 & 44.1 & 46.2 & 42.1 \\
\hline \multicolumn{6}{|c|}{$\begin{array}{l}\text {... according to highest education level } \\
\text { of parents: }\end{array}$} \\
\hline \multicolumn{2}{|c|}{ University degree } & 182 & 34.8 & 28.9 & 39.8 \\
\hline \multicolumn{2}{|c|}{ No university degree } & 367 & 49.5 & 55.4 & 43.8 \\
\hline \multicolumn{2}{|l|}{ Missings } & 0 & & & \\
\hline \multicolumn{6}{|c|}{... according to household net equivalent income: } \\
\hline \multicolumn{2}{|c|}{ Average income group } & 318 & 46.2 & 49.1 & 43.4 \\
\hline \multicolumn{2}{|c|}{ Low income group (< 70\%) } & 148 & 41.2 & 42.4 & 40.2 \\
\hline \multicolumn{2}{|l|}{ Missings } & 0 & & & \\
\hline \multicolumn{6}{|c|}{... according to class affiliation of parents: } \\
\hline \multicolumn{2}{|c|}{ The salariat } & 135 & 45.9 & 48.5 & 43.3 \\
\hline \multicolumn{2}{|c|}{ The intermediate class } & 163 & 38.7 & 41.7 & 36.3 \\
\hline \multicolumn{2}{|c|}{ The working class } & 236 & 47.0 & 47.9 & 46.2 \\
\hline \multicolumn{2}{|l|}{ Missings } & 15 & & & \\
\hline \multicolumn{6}{|c|}{$\begin{array}{l}\text {...according to educational aspirations } \\
\text { for children: }\end{array}$} \\
\hline \multicolumn{2}{|c|}{ University degree } & 178 & 37.6 & 36.6 & 44.4 \\
\hline \multicolumn{2}{|c|}{ No university degree } & 368 & 47.6 & 50.8 & 38.5 \\
\hline \multicolumn{2}{|l|}{ Missings } & 3 & & & \\
\hline \multicolumn{6}{|c|}{$\begin{array}{l}\text {... according to school performance } \\
\text { of the children: }\end{array}$} \\
\hline \multirow[t]{4}{*}{ Math } & Above average (grades 1 or 2 ) & 193 & 28.5 & 31.9 & 25.3 \\
\hline & Average (grade 3) & 189 & 47.6 & 48.8 & 46.7 \\
\hline & Below average (grades 4,5 , or 6 ) & 157 & 59.2 & 61.3 & 57.1 \\
\hline & Missings & 10 & & & \\
\hline \multirow[t]{4}{*}{ German } & Above average (grades 1 or 2 ) & 224 & 33.0 & 27.6 & 35.8 \\
\hline & Average (grade 3) & 229 & 50.2 & 52.1 & 48.2 \\
\hline & Below average (grades 4,5 , or 6 ) & 86 & 58.1 & 62.1 & 50.0 \\
\hline & Missings & 10 & & & \\
\hline \multirow[t]{4}{*}{ English } & Above average (grades 1 or 2 ) & 206 & 27.7 & 23.5 & 30.4 \\
\hline & Average (grade 3) & 193 & 49.7 & 55.7 & 43.8 \\
\hline & Below average (grades 4,5 , or 6 ) & 135 & 60.7 & 60.0 & 61.7 \\
\hline & Missings & 15 & & & \\
\hline
\end{tabular}




\begin{tabular}{|c|c|c|c|c|}
\hline & \multirow{2}{*}{$\begin{array}{c}N \\
\text { (total) }\end{array}$} & \multicolumn{3}{|c|}{ Proportion of SE users (in \%) } \\
\hline & & Total & $\begin{array}{c}\text { Boys } \\
(N=264)\end{array}$ & $\begin{array}{c}\text { Girls } \\
(N=285)\end{array}$ \\
\hline $\begin{array}{l}\text {...according to attended school level of the } \\
\text { children: }\end{array}$ & & & 46.7 & 53.5 \\
\hline Upper secondary school level & 142 & 50.7 & & \\
\hline Lower secondary school level & 387 & 42.1 & 46.4 & 37.5 \\
\hline Missings & 20 & & & \\
\hline \multicolumn{5}{|l|}{$\begin{array}{l}\text {...according to attended school track of the } \\
\text { children: }\end{array}$} \\
\hline Abitur program (university entrance certificate) & 341 & 46.3 & 49.1 & 44.0 \\
\hline Real- or Hauptschule degree program & 167 & 38.3 & 43.9 & 32.9 \\
\hline Missings & 41 & & & \\
\hline \multicolumn{5}{|l|}{$\begin{array}{l}\text {...according to educational aspirations of the } \\
\text { children: }\end{array}$} \\
\hline University degree & 235 & 44.7 & 45.4 & 44.2 \\
\hline No university degree & 303 & 42.6 & 45.1 & 39.7 \\
\hline Missings & 11 & & & \\
\hline
\end{tabular}

Source: LifE 2012, own calculation.

Our data also show differences in the use of SE by gender according to school grades, the school level and track. Girls with above-average grades in mathematics took less SE (about 25\%) than boys (about 32\%). For the domains German and English, the opposite is found. These differences between genders are non-significant, though. Both genders more frequently obtained tutoring if they attended the upper secondary school level and/or pursued the Abitur. However, only girls obtained significantly more often SE if they were enrolled in the Abitur track or at the upper secondary school level. Significant gender differences in students' own post-secondary aspirations are not discernible.

The correlations between the predictor variables are mostly weak. Parental education is positively correlated with household-net-income (.26) and class (.24), with the latter two being also weakly correlated with each other (.18). Notable correlations also exist for educational aspirations of parents and students (.36) as well as for students' grades in the three different subject areas German, mathematics and English (.34 to .56).

\subsection{Multivariate results}

Table 2 summarizes the results of the stepwise logistic regressions to test our first set of hypotheses. Model 1 examines the influence of parental SES on the likelihood of students to have obtained SE. As expected in hypothesis 1-1 and indicated by our descriptive findings, parental education is negatively associated with SE 
$28(-15 \%$ probability if parents possess university degree). Other SES factors show no significant effects. In Model 2 we test whether the overall performance level of the students affects their involvement with SE. Results show that - despite possible endogeneity and a lack of time structure - performance is the most significant predictor for SE, reporting the highest $\mathrm{R}^{2}(.08)$ among the first set of separated models. Compared to average performing students, above average performers in math and English are significantly less likely to have obtained SE, whereas no significant differences are found for the performance in German. Conversely, this supports hypothesis 1-2: Students with below-average (and average) performance are far more likely to have experience with SE. Model 3 then tests school institutional factors' influence on the likelihood to have obtained SE: Students pursuing the Abitur (+9\%, significant at the 10\% level) are more likely to seek SE (supporting hypothesis 1-3). Model 4 then tests the influence of parents' and students' post-secondary aspirations showing unexpected results: If parents wish for their children to enter tertiary education, the children will be significantly less likely to have obtained SE (contrary to hypothesis 1-4). Model 5 focuses on the association between gender and SE, showing that a student's gender does not show any obvious effect on tutoring attendance. In Model 6 we included all predictor variables and find robust effects of parental education, performance level, and school track. Parental educational aspirations are now mediated through their education background and reduced to insignificance, whereas students' own aspirations become more important (+13\%). Even though the $R^{2}$ is quite low for SES variables (Model 1: .02), educational background remains a robust factor for SE participation. These first results support the notion that SE is primarily used by non-academic families to compensate low performance rather than serving status maintenance of high SES families.

To test for interaction effects between gender and educational background, in Table 3, we first differentiated our analyses by students' gender (Model 7) and found astounding differences: While parental education level shows a massive impact on the boys' SE attendance ( $-27 \%$ probability if parents possess university education), there are no effects for girls. This difference in average probability between genders is highly significant (see M7 Diff. $P>|t|$; confirming hypothesis 2-1). Hence, there exist clear intersectionalities between gender and parental education in SE investment. Even though there seem to exist differences in the effects of performance, school level, and aspirations on SE between gender, these differences are statistically non-significant with the exception of school level (at the 0.1-level). Thus, girls attending the upper secondary schooling level are significantly more likely than boys to have obtained SE. 


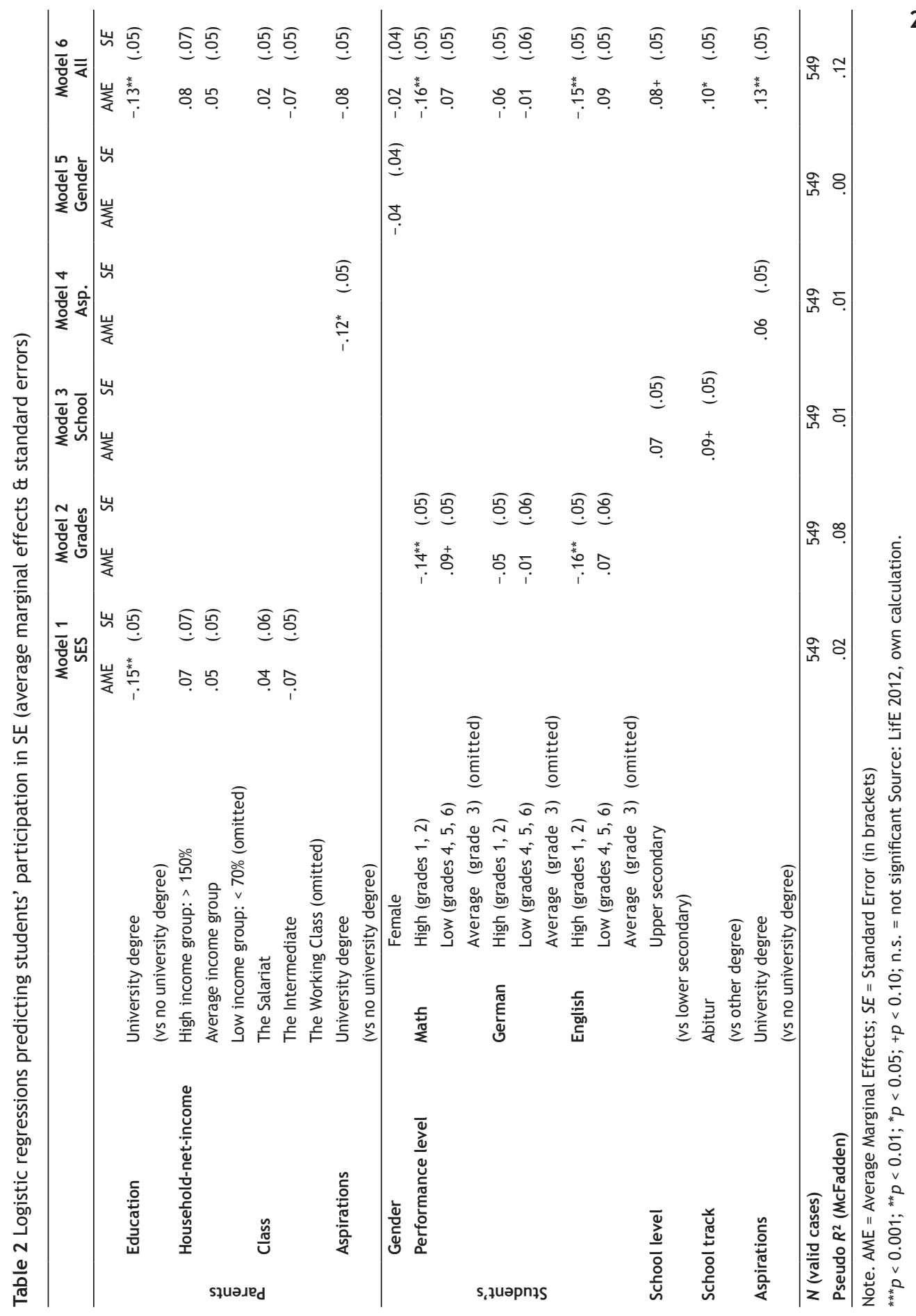


30 Table 3 Logistic regressions predicting students' participation in SE (average marginal effects \& standard errors)

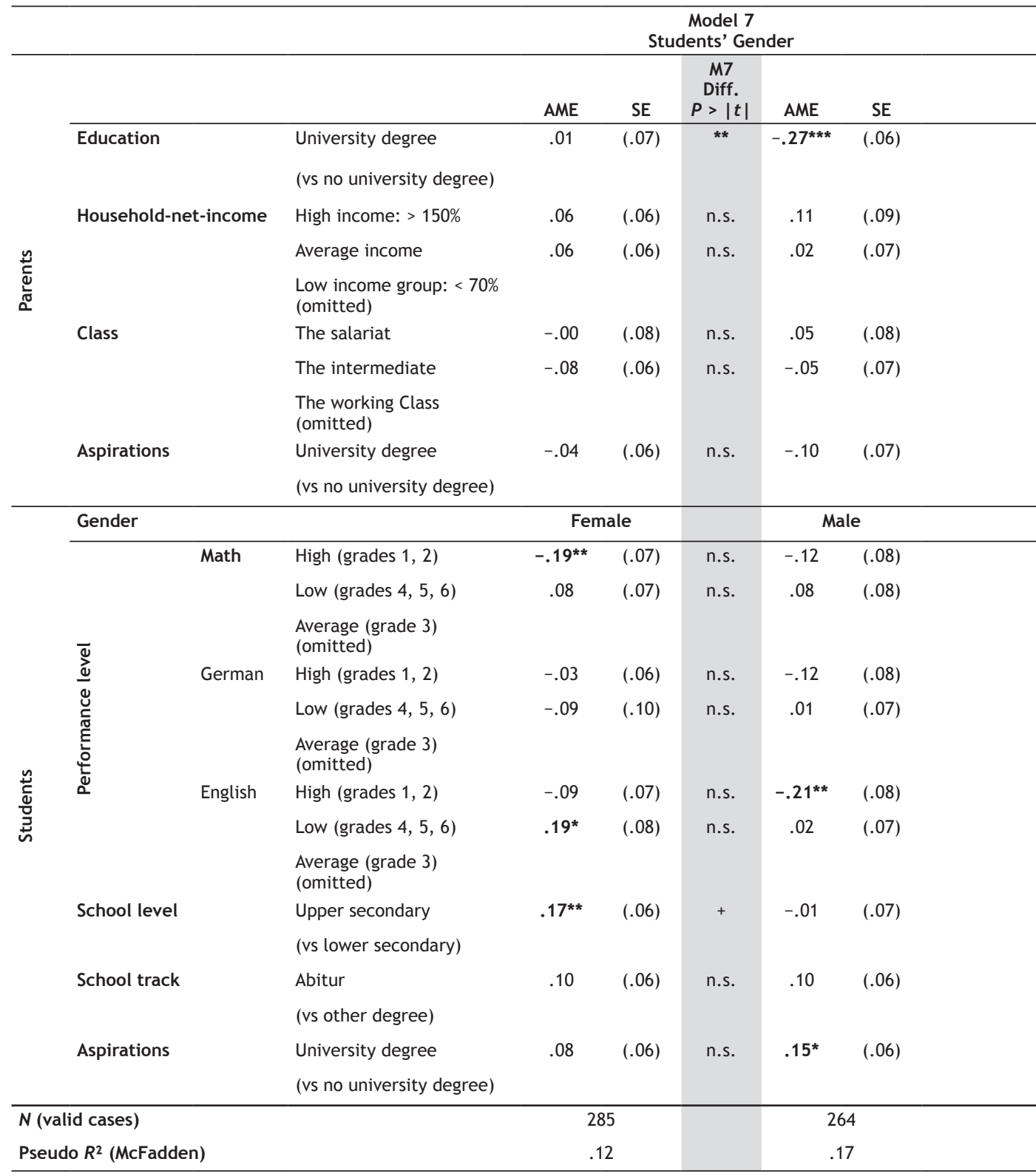

Note. $\mathrm{AME}=$ Average Marginal Effects; $S E=$ Standard Error (in brackets); Diff. $\mathrm{P}>|t|=$ Difference between predictors across models: significant or not.

${ }^{* * *} p<0.001 ;{ }^{* *} p<0.01 ;{ }^{*} p<0.05 ;+p<0.10 ;$ n.s. = not significant

Source: LifE 2012, own calculation. 
Model 8

Parents' Education x Students' Gender

\begin{tabular}{|c|c|c|c|c|c|c|c|c|c|c|}
\hline AME & $\begin{array}{c}M 8-1 \\
\text { Diff. } \\
P>|t|\end{array}$ & AME & SE & AME & SE & $\begin{array}{c}M 8-2 \\
\text { Diff. } \\
P>|t|\end{array}$ & AME & $S E$ & $\begin{array}{c}\text { M8-3 } \\
\text { Diff. } \\
P>|t|\end{array}$ & $\begin{array}{c}\text { M8-4 } \\
\text { Diff. } \\
P>|t|\end{array}$ \\
\hline Univers & degree ( & en & & & & $\begin{array}{l}\text { versity } \\
\text {--acade }\end{array}$ & ree & & With & gender \\
\hline
\end{tabular}

n.s. $\quad .04$

.12

n.s. $\quad .23+$

n.s. n.s.

.13

n.s.

.07

(.11)

.04

(.07)

n.s.

.01

(.08)

n.s. n.s.

.08

$$
\text { n.s. } \quad-.06
$$

(.12) -.05

(.10)

n.s. $\quad .08$

n.s. n.s.

$.01 \quad(.12)$

n.s.

$-.14$

(.12)

(.08)

n.s. -.05

(.09)

n.s. n.s.

$-.03 \quad(.09)$

n.s. $\quad-.24^{*} \quad(.09) \quad-.04 \quad(.08)$

n.s. $\quad-.03$

(.10)

n.s.

Female Male $\quad$ Female

Male

Fem

$-.09$

.12

(.11)

n.s.

$-.18$

(.13)

$-.25^{* *}$

(.09)

n.s.

(.09)

n.s.

$-.13$

(.09)

Female Male

n.s.

$-.00$

(.14)

.09

n.s.

.08

(.09)

n.s.

n.s.

n.s.

$-.09$

n.s. -.13

(.13)

$.01 \quad(.08)$

n.s.

$-.12$

(.10)

n.s.

$.20 \quad(.19)$

n.s.

$-.02$

(.13) $-.21^{*} \quad(.10)$

n.s.

.00

(.09)

$+$

n.s.

$.09 \quad(.12) \quad$ n.s. $\quad-.14 \quad(.12) \quad-.16+\quad(.08)$

$.51 * * \quad(.15)$

$+.10$

(.15) $\quad .09 \quad(.10)$

n.s. $-.26 * *$

(.10)

n.s. $\quad-.00 \quad(.09)$

n.s

n.s.

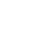

$.20+$

$$
\text { n.s. }
$$

.03

$.15^{*}$

(.07)

n.s.

$-.00$

n.s.

$-.02$

n.s.

.13

(.12)

$.14+\quad(.07)$

n.s.

.12

(.08)

n.s.

n.s.

.05

n.s.

.09

(.11)

$.09 \quad(.09)$

n.s

.20 **

(.08)

n.s.

n.s.

$\begin{array}{lr}83 & 186 \\ .22 & .16\end{array}$

181

Note. $\mathrm{AME}=$ Average Marginal Effects; $\mathrm{SE}=$ Standard Error (in brackets); Diff. $\mathrm{P}>|t|=$ Difference between predictors across models: significant or not.

${ }^{* * *} p<0.001 ;{ }^{* *} p<0.01 ;{ }^{*} p<0.05 ;+p<0.10$; n.s. = not significant

Source: LifE 2012, own calculation. 
Finally, in Model 8 we further differentiated our analyses according to parental educational background. First, we take a look at the displayed effects within the models before investigating whether the found effects differ significantly between the four sub-groups. As for children from academic backgrounds, it appears that girls are significantly more likely to have obtained SE if they show below average performance in English and are enrolled at the upper secondary school level. For boys from the same backgrounds we find a lower likelihood of SE if their parents want them to enter university in the future. These gender differences are significant in the case of English performance: Among academic strata, girls are more likely than boys to have obtained SE if they show below average performance in English (see M8-1 Diff. $P>|t|)$. Girls' support in foreign language proficiency in English seems to be more highly valued among academic families.

In the case of children from non-academic families, we find that boys' likelihood to have obtained SE is significantly higher $(+23 \%)$ if they come from high-income families, or show high post-secondary aspirations $(+20 \%)$, thus supporting hypothesis 2-2. However, we cannot confirm that this effect is significantly different from other subgroups (see M8-2/3/4 Diff. $P>|t|$ ). Girls from non-academic backgrounds show a lower likelihood to obtain SE if they come from the intermediate class, are enrolled at the upper secondary school level and/or pursue the Abitur, and show above average performance in math and English or below average performance in German. Significant gender differences in the effects of the predictor variables for students from non-academic backgrounds are not found (see M8-2 Diff. $P>|t|$ ).

However, the last result for girls is particular interesting, especially if compared with the results for girls from academic backgrounds (see M8-3 Diff. $P>|t|$ ). Comparing genders across different educational backgrounds shows that academic parents are significantly more likely to invest in the SE of their low-performing daughters (in German and English) than non-academics. These results thus support hypothesis 2-3. As for boys, we find a significant difference in parental aspirations. Thus, boys from academic backgrounds are less likely to obtain SE if their parents wish for them to enter university in the future. But no such relationship exists for boys from non-academic backgrounds.

\section{Discussion}

In the present work, we questioned the causes for the strong increase in the use of SE in Germany over the past two decades. We attempted to explain this development through gender- and SES- (education) specific familial investment strategies. In contrast to international findings and prominent theses, our results show that SE in Germany does not serve as a tool to promote social inequality. SE is more prevalent among lower performing male students from non-academic family backgrounds. This holds especially for the student group who intend to achieve the Abitur and enter tertiary education afterwards (thus confirming the first set of hypotheses). The lack 
of (positive) parental aspirations towards the university entrance of their children

further strengthens the view that primarily status upgrade motives of non-academic families have caused the higher SE investment in Germany - not status maintenance motives of high SES families. SE in Germany seems to compensate challenges at school for students from non-academic families instead of promoting social distinction.

Differentiated regression models showed that gender plays a significant role in the reception of tutoring, suggesting different educational investment strategies based on gender-specific status attainment goals. We found considerable interaction effects between gender and parental education on SE investment. First of all, boys from non-academic families are most likely to obtain SE. Secondly, these boys are also significantly more likely to have obtained SE than girls, for whom no influence of parental education or other SES factors could be verified (confirming hypothesis 2-1). In addition, higher income and aspirations (of the students themselves, not the parents) seem to play a more important role for SE attainment of boys from non-academic strata compared to other students (confirming hypothesis 2-2). Third, girls' SE attainment seems unaffected by their SES in general, but there are significant differences in the likelihood of low performing girls to have obtained SE according to parental education. Girls with below average performance in languages are more likely to experience SE if they come from academic instead of non-academic families (confirming hypothesis 2-3). In these cases, status maintenance rather than upgrade motives drives the girls' SE attainment. For girls' performance in mathematics no significant differences were found, though.

In conclusion, this first-time investigation of SES- and gender-specific differences in SE investment reveals some interesting differences in family investment behavior. Not only could we show that tutoring in Germany depends less than expected on the socio-economic situation of the household; boys from disadvantaged educational backgrounds are even more likely to obtain SE, thereby possibly counteracting a widening of the SES- and gender-achievement gap. Our findings indicate first concrete intersectionalities between gender and SES in SE use for Germany insofar as non-academic families are more likely using SE for compensatory purposes for boys, whereas highly educated families also use SE for girls for status maintenance. Although variations in the quantity and quality of SE may largely affect these findings, because then the financial resources of the family become more important, existing surveys actually show that the bulk of spending on tutoring in Germany is rather moderate in nature and hardly comparable to spending in countries with sophisticated tutoring systems (Birkelbach et al., 2017).

Overall, it seems as if there still exists a lack of incentives for high SES families in Germany to use tuition for status-promotion, such as "gatekeeper" exams that determine transitions to the upper secondary or tertiary education levels. ${ }^{11}$ Still, this paper provides a good start for future research, which should further clarify

11 Prominent examples are the SAT in the United States and the entrance exams in Japan, South Korea, or China. 
34 how SES affects differences in SE reception of different quantity and quality. So far, however, the prominent assumption that SE serves high strata as an instrument of social exclusion proves to be untenable on the basis of the presented findings, especially for boys. Families primarily try to ensure that their children compensate the increasing requirements as they went through school. Especially if the demands in school are high, for example if students aspire to graduate with the Abitur, tutoring might serve to avoid dropping out by compensating the higher requirements of this degree track. Even if it remains doubtful that SE possesses the power to significantly improve the performance of students from below average to average or even above average performance, German families may well use SE to increase the chances of their children to achieve the highest school degree and through this achieve a status upgrade. Future research should thus also investigate the actual effects of SE on allocation to the upper secondary and tertiary education levels. Research in this direction is common in many countries, but non-existent for Germany.

Based on our findings, the general increase in the use of SE in Germany should be understood as a consequence of educational expansion. One the one hand, the lack of remedial, individual support for the increasing number of students (esp. girls) entering higher school tracks (e.g., leading to the Abitur) caused demand for individual support through supplementary tutoring. On the other hand, the high ambitions of students from non-academic backgrounds (esp. boys) to achieve higher educational credentials than their parents (status upgrade motive) furthered SE participation.

The significant differences in the general and education background-specific use of tutoring by gender and the implicit effects on student achievement call into question the assumptions of prominent inequality theories. The here presented rational choice and effectively maintained inequality approaches better explain why boys from low SES families would receive tutoring for status upgrade. However, why the investment in girls' SE is largely unaffected by parental SES in general and why lower performing girls from non-academic backgrounds are less likely to have obtained SE than girls from academic backgrounds is up to now not well explained. That's because evidence suggests that SE provides its customers in Germany with no enhancement features similar to those found in other national settings (e.g., exam preparation in the United States or in East Asia). Thus, incentives for high SES families to invest in SE to achieve advantages in the competition for credentials are scarce at best. SES and gender are largely intertwined when it comes to educational investment strategies of families. A fact that needs to be better investigated in future research. Even though our findings are far from conclusive since we cannot test for long-term effects of SE on boys' and girls' educational attainment and progress, our findings point to the need of developing social reproduction theories to stronger address gender disparities in educational decisions.

Our findings call for similar approaches in other national settings to explore the role of family status motives for the increasing demand for tutoring and its implications for inequality persistence and gender disparities. In this regard, systematic research on the relationship between gender-specific investments in SE and the 
recent trend of female educational advantage in many schooled societies should be investigated throughoutly, as already suggested by Park et al. (2016). Also, a future review of our results over time (trend analysis) and the analysis of long-term effects of SE, especially for school allocation and transition to university seems promising.

\section{References}

Abele, A., \& Liebau, E. (1998). Nachhilfeunterricht. Eine empirische Studie an bayerischen Gymnasien. Die Deutsche Schule, 90(1), 37-49.

Baker, D. P., Akiba, M., LeTendre, G. K., \& Wiseman, A. W. (2001). Worldwide shadow education: Outside-school learning, institutional quality of schooling, and cross-national mathematics achievement. Educational Evaluation and Policy Analysis, 23(1), 1-17.

Baumert, J., Maaz, K., \& Trautwein, U. (Eds.). (2010). Bildungsentscheidungen. Wiesbaden: VS Verl. für Sozialwiss.

Becker, R., \& Lauterbach, W. (Eds.). (2016). Bildung als Privileg - Erklärungen und Befunde zu den Ursachen der Bildungsungleichheit. Wiesbaden: VS Springer.

Becker, R., \& Müller, W. (2011). Bildungsungleichheiten nach Geschlecht und Herkunft im Wandel. In A. Hadjar (Ed.), Geschlechtsspezifische Bildungsungleichheiten (pp. 55-75). Wiesbaden: VS Verlag.

Behr, M. (1990). Nachhilfeunterricht. Erhebungen in einer Grauzone pädagogischer Alltagsrealität. Darmstadt: Wissenschaftliche Buchgesellschaft.

Birkelbach, K., Dobischat, R., \& Dobischat, B. (2017). Ausserschulische Nachhilfe - Ein prosperierender Bildungsmarkt im Spannungsfeld zwischen kommerziellen und öffentlichen Interessen. Düsseldorf: Hans-Böckler-Stiftung.

Boudon, R. (1974). Education, opportunity, and social inequality: Changing prospects in Western society. New York: Wiley.

Bray, M. (1999). The shadow education system: Private tutoring and its implications for planners. Paris: UNESCO, International Institute for Educational Planning.

Bray, M. (2009). Confronting the shadow education system: What government policies for what private tutoring? Paris: UNESCO International Institute for Educational Planning.

Bray, M. (2017). Schooling and its supplements: Changing global patterns and implications for comparative education. Comparative Education Review, 61(3), 469-491.

Breen, R., \& Goldthorpe, J. H. (1997). Explaining educational differentials - Towards a formal rational action theory. Rationality and Society, 9(3), 275-305.

Breen, R., Luijkx, R., Müller, W., \& Pollak, R. (2012). Bildungsdisparitäten nach sozialer Herkunft und Geschlecht im Wandel - Deutschland im internationalen Vergleich. In R. Becker \& H. Solga (Eds.), Soziologische Bildungsforschung, Sonderheft 52 Kölner Zeitschrift für Soziologie und Sozialpsychologie (pp. 346-373). Wiesbaden: Springer.

Buchmann, C., Condron, D. J., \& Roscigno, V. J. (2010). Shadow education, American style: Test preparation, the SAT and college enrollment. Social Forces, 89(2), 435-462.

Byun, S. (2014). Shadow education and academic success in Republic of Korea. In H. Park \& K. Kim (Eds.), Korean education in changing economic and demographic contexts (pp. 39-58). Dordrecht: Springer.

Byun, S., Chung, H. J., \& Baker, D. P. (2018). Global patterns of the use of shadow education: Student, family, and national influences. Research in the Sociology of Education, 20, 71-105.

DiPrete, T. A., \& Buchmann, C. (2013). The rise of women: The growing gender gap in education and what it means for American schools. New York: Russel Sage Foundation.

Dohmen, D., Erbes, A., Fuchs, K., \& Günzel, J. (2008). Was wissen wir über Nachhilfe? Sachstand und Auswertung der Forschungsliteratur zu Angebot, Nachfrage und Wirkungen. Bielefeld: Bertelsmann 
36 Entrich, S. R. (2014a). Effects of investments in out-of-school education in Germany and Japan. Contemporary Japan, 26(1), 71-102.

Entrich, S. R. (2014b). German and Japanese education in the shadow: Do out-of-school lessons really contribute to class reproduction? IAFOR Journal of Education, 2(2), 17-53.

Entrich, S. R. (2015). The decision for shadow education in Japan: Students' choice or parents' pressure? Social Science Japan Journal, 18(2), 193-216.

Entrich, S. R. (2018). Shadow education and social Inequalities in Japan. Evolving Patterns and Conceptual Implications. Heidelberg: Springer.

Entrich, S. R. (2020). Worldwide shadow education and social inequality: Explaining differences in the socioeconomic gap in access to shadow education across 63 societies. International Journal of Comparative Sociology, 62. Preprint doi: 10.13140/RG.2.2.25983.76961

Entrich, S. R., \& Lauterbach, W. (2019). Shadow education in Germany: Compensatory or status attainment strategy? Findings from the German LifE study. International Journal of Research on Extended Education, 7(2), 143-159.

Guill, K. (2012). Nachhilfeunterricht. Individuelle, familiäre und schulische Prädiktoren. Münster, New York, München, Berlin: Waxmann.

Guill, K., \& Bonsen, M. (2011). Prädiktoren der Inanspruchnahme von Nachhilfeunterricht am Beginn der Sekundarstufe I. Empirische Pädagogik, 25(3), 307-330.

Guill, K., \& Bos, W. (2014). Effectiveness of private tutoring in mathematics with regard to subjective and objective indicators of academic achievement. Journal for Educational Research Online, 6(1), 34-67.

Guill, K., \& Lintorf, K. (2019). Private tutoring when stakes are high: Insights from the transition from primary to secondary school in Germany. International Journal of Educational Development, 65, 172-182.

Guill, K., Lüdtke, O., \& Köller, O. (2020). Assessing the instructional quality of private tutoring and its effects on student outcomes: Analyses from the German National Educational Panel Study. British Journal of Educational Psychology, 90(2), 282-300.

Guill, K., \& Spinath, B. (2014). Special Issue Editorial: Effects of private tutoring. Journal for Educational Research Online, 6(1), 7-11.

Hadjar, A. (Ed.). (2011). Geschlechtsspezifische Bildungsungleichheiten. Wiesbaden: VS Verlag.

Hadjar, A., \& Berger, J. (2010). Dauerhafte Bildungsungleichheiten in Westdeutschland, Ostdeutschland und der Schweiz: Eine Kohortenbetrachtung der Ungleichheitsdimensionen soziale Herkunft und Geschlecht. Zeitschrift für Soziologie, 39(3), 182-201.

Hadjar, A., \& Berger, J. (2011). Geschlechtsspezifische Bildungsungleichheiten in Europa: Die Bedeutung des Bildungs- und Wohlfahrtsstaatssystems. In A. Hadjar (Ed.), Geschlechtsspezifische Bildungsungleichheiten (pp. 23-54). Wiesbaden: VS Verlag.

Helbig, M. (2012). Sind Mädchen besser? Der Wandel geschlechtsspezifischen Bildungserfolgs in Deutschland. Frankfurt, New York: Campus.

Helbig, M. (2013). Geschlechtsspezifischer Bildungserfolg im Wandel. Eine Studie zum Schulverlauf von Mädchen und Jungen an allgemeinbildenden Schulen für die Geburtsjahrgänge 1944-1986 in Deutschland. Journal for Educational Research Online, 5(1), 141-183.

Hille, A., Spieß, C. K., \& Staneva, M. (2016). Immer mehr Schülerinnen und Schüler nehmen Nachhilfe. DIW-Wochenbericht, 83(6), 111-121.

Hollenbach, N., \& Meier, U. (2004). Lernen am Nachmittag - Häusliche Unterstützung und bezahlte Nachhilfe von 15-Jährigen. In G. Schümer, K.-J. Tillmann, \& M. Weiß (Eds.), Die Institution Schule und die Lebenswelt der Schüler. Vertiefende Analysen der PISA-2000-Daten zum Kontext von Schülerleistungen (pp. 165-186). Wiesbaden: SpringerVS.

Hosenfeld, I. (2011). Wirkungen von Mathematiknachhilfe bei rheinland-pfälzischen Schülern fünfter Klassen: Eine längsschnittliche Analyse. Empirische Pädagogik, 25(3), 331-341.

Ireson, J., \& Rushforth, K. (2011). Private tutoring at transition points in the English education system: Its nature, extent and purpose. Research Papers in Education, 26(1), 1-19.

Jürgens, E., \& Diekmann, M. (2007). Wirksamkeit und Nachhaltigkeit von Nachhilfeunterricht: Dargestellt am Beispiel des Studienkreises. Frankfurt am Main: Peter Lang. 
Klemm, K., \& Hollenbach-Biele, N. (2016). Nachhilfeunterricht in Deutschland: Ausmaß-Wirkung-Kosten. Gütersloh: Bertelsmann Stiftung.

Klemm, K., \& Klemm, A. (2010). Ausgaben für Nachhilfe: Teurer und unfairer Ausgleich für fehlende individuelle Förderung. Gütersloh: Bertelsmann Stiftung.

Koinzer, T. (2013). Supplementary education in Germany: History and present developments. In J. Aurini, S. Davies, \& J. Dierkes (Eds.), Out of the shadows: The global intensification of supplementary education (pp. 209-220). Bingley: Emerald Publishing.

Lauterbach, W., Fend, H., \& Gläßer, J. (2016). LifE - Lebensverläufe von der späten Kindheit ins fortgeschrittene Erwachsenenalter. Beschreibung der Studie. Potsdam: Universitätsverlag Potsdam.

Lee, S., \& Shouse, R. C. (2011). Impact of prestige orientation on shadow education in South Korea. Sociology of Education, 84(3), 212-224.

Liu, J., \& Bray, M. (2016). Determinants of demand for private supplementary tutoring in China: Findings from a national survey. Education Economics, 25(2), 1-14.

Lucas, S. R. (2001). Effectively maintained inequality. Education transitions, track mobility, and social background effects. American Journal of Sociology, 106(6), 1642-1690.

Lühe, J., Becker, M., Neumann, M., \& Maaz, K. (2016). Geschlechtsspezifische Leistungsunterschiede in Abhängigkeit der sozialen Herkunft. Eine Untersuchung zur Interaktion zweier sozialer Kategorien. Zeitschrift für Erziehungswissenschaft, 20, 499-519.

Lühe, J., Becker, M., Neumann, M., \& Maaz, K. (2017). Zur Bedeutung der sozialen Herkunft für Geschlechterunterschiede im Bildungserfolg. Zeitschrift für Soziologie der Erziehung und Sozialisation, 37(4), 416-436.

Luplow, N., \& Schneider, T. (2014). Nutzung und Effektivität privat bezahlter Nachhilfe im Primarbereich. Zeitschrift für Soziologie, 43(1), 31-49.

Marchenko, Y. (2011). Chained equations and more in multiple imputation in Stata 12 [Presentation]. United Kingdom Stata Users' Group Meetings 2011.

Mood, C. (2010). Logistic regression. Why we cannot do what we think we can do, and what we can do about it. European Sociological Review, 26(1), 67-82.

Ömeroğulları, M., Guill, K., \& Köller, O. (2020). Effectiveness of private tutoring during secondary schooling in Germany: Do the duration of private tutoring and tutor qualification affect school achievement? Learning and Instruction, 66, 1-23.

Park, H., Buchmann, C., Choi, J., \& Merry, J. J. (2016). Learning beyond the school walls: Trends and implications. Annual Review of Sociology, 42, 231-252.

Rudolph, M. (2002). Nachhilfe - gekaufte Bildung? Empirische Untersuchung zur Kritik der außerschulischen Lernbegleitung. Eine Erhebung bei Eltern, LehrerInnen und Nachhilfeinstituten. Bad Heilbrunn: Klinkhardt.

Safarzynska, K. (2013). Socio-economic determinants of demand for private tutoring. European Sociological Review, 29(2), 139-154.

Schafer, J. L., \& Graham, J. W. (2002). Missing data: Our view of the state of the art. Psychological Methods, 7(2), 147-177.

Schlösser, H.-J., \& Schuhen, M. (2011). Führt Nachhilfe zu Wettbewerbsverzerrungen? Empirische Pädagogik, 25(3), 370-379.

Schneider, T. (2005). Nachhilfe als Strategie zur Verwirklichung von Bildungszielen. Eine empirische Untersuchung mit Daten des Sozio-oekonomischen Panels (SOEP). Zeitschrift für Pädagogik, 51(3), 363-379.

Seiyama, K., \& Noguchi, Y. (1984). Kōkō shingaku ni okeru gakkōgai kyōiku tōshi no kōka [The Effects of Outside of School Educational Investments at the Transition to High School]. Kyōiku Shakaigaku Kenkyū, 39, 113-126.

Shavit, Y., \& Park, H. (2016). Introduction to the special issue: Education as a positional good. Research in Social Stratification and Mobility, 43(1), 1-5.

Stevenson, D. L., \& Baker, D. P. (1992). Shadow education and allocation in formal schooling: Transition to university in Japan. American Journal of Sociology, 97, 1639-1657.

Tsching, S., Berichte, R., \& Fend, H. (1983). Merkmale des Konstanzer Jugendlängsschnitts. Design Durchführung, Teilnahme, Ausfälle. Konstanz: Universitätsschriften. 
38 Weiss, F., \& Schindler, S. (2017). EMI in Germany: Qualitative differentiation in a tracked education system. American Behavioral Scientist, 61(1), 74-93.

Wirth, H., \& Fischer, A. (2008). ESeC - European Socioeconomic Classification. Die Operationalisierung von ESeC im kumulierten ALLBUS 1980-2006. Retrieved from: http: / / www.ssoar .info/ssoar/handle/document/20692

Acting Prof. Dr. Steve R. Entrich Inclusion and Organizational Development, University of Potsdam

Campus Golm

Haus 31, Raum 1.06

Karl-Liebknecht-Str. 24-25

14476 Potsdam

Germany

entrich@uni-potsdam.de

Prof. Dr. Wolfgang Lauterbach Social Science Education Research, University of Potsdam

Campus Golm

Haus 24, Raum 1.68

Karl-Liebknecht-Str. 24-25

14476 Potsdam

Germany

wolfgang.lauterbach@uni-potsdam.de 